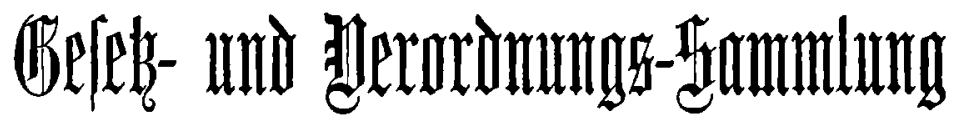

für

Bolizei= umb Giemeindebehörben, (Sierichte, Rechtganmälte und $B$ Bürger $2 \mathfrak{c}$.

bes

\section{Söntgreidjs @̧anern}

unter befonberer Berüdfictitigung

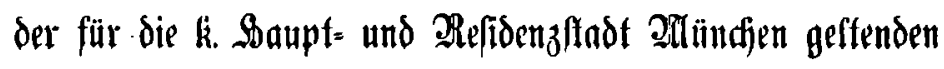
orf5pofizeilitiden כorldiriften

von

A. Zittex.

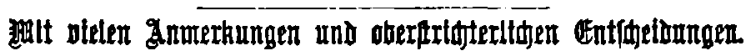

Alïnđุ̣n 1893.

Druaf und Derlag von $\mathfrak{R}$. Oidenbourg. 
